\title{
The crystal structure of eulytite $\mathrm{Pb}_{3} \mathrm{BiV}_{3} \mathrm{O}_{12}$
}

\author{
Prangya Parimita Sahoo ${ }^{a}$, Etienne Gaudin ${ }^{b}$, Jacques Darriet ${ }^{b}$, T.N. Guru Row ${ }^{\text {a,* }}$ \\ a Solid State and Structural Chemistry Unit, Indian Institute of Science, C.V. Raman Avenue, Bangalore 560012, Karnataka, India \\ ${ }^{\mathrm{b}}$ CNRS, Université de Bordeaux, ICMCB, 87 Avenue du Dr. A. Schweitzer, Pessac F-33608, France
}

\section{A R T I C L E I N F O}

\section{Article history:}

Received 7 July 2008

Received in revised form 8 September 2008

Accepted 17 September 2008

Available online 4 October 2008

\section{Keywords:}

A. Inorganic compound

A. Oxides

B. Crystal growth

C. X-ray diffraction

D. Crystal structure

\begin{abstract}
A B S T R A C T
The crystal structure of $\mathrm{Pb}_{3} \mathrm{BiV}_{3} \mathrm{O}_{12}$ was solved using single-crystal $\mathrm{X}$-ray diffraction technique. The compound crystallizes in the cubic system $I \overline{4} 3 d$ (No. 220) with eulytite structure with $a=10.7490(7) \AA$, $V=1241.95(14) \AA^{3}$ and $Z=4$. The final $R_{1}$ value of $0.0198\left(w R_{2}=0.0384\right)$ was achieved for 359 independent reflections during the structure refinement. The $\mathrm{Pb}^{2+}$ and $\mathrm{Bi}^{3+}$ cations occupy the special position (16c) while the oxygen anions occupy the general position (48e) in the crystal structure. Unlike many other eulytite compounds, all the crystallographic positions are fully occupied. The structure consists of edge-shared $\mathrm{Pb} / \mathrm{Bi}$ octahedra linked at the corners to independent $\left[\mathrm{VO}_{4}\right]^{3-}$ tetrahedra units, generating a eulytite-type network in the crystal lattice.
\end{abstract}

(c) 2008 Elsevier Ltd. All rights reserved.

\section{Introduction}

$\mathrm{Bi}_{4}\left(\mathrm{SiO}_{4}\right)_{3}$ (BSO) is the first eulytite-type compound to be identified to belong to the space group $I \overline{4} 3 d$ as determined by Menzer [1]. Ever since its discovery, $\mathrm{Bi}_{4}\left(\mathrm{SiO}_{4}\right)_{3}$ (BSO) and its germanate analogue $\mathrm{Bi}_{4}\left(\mathrm{GeO}_{4}\right)_{3}$ (BGO) have attracted researchers' interest because of their applications as luminescent materials. Both powder and single-crystal X-ray and neutron diffraction studies have been performed to unequivocally establish the structure [2-6] of these isotypic compounds. Single crystals were grown by Czochralski method for BSO and BGO [7-9]. Since then, a number of compounds that belong to different eulytite series have been synthesized over a period of time by appropriate substitution at $\mathrm{Bi}$ and $\mathrm{Si}$ sites. They are $\mathrm{A}_{3} \mathrm{~B}\left(\mathrm{XO}_{4}\right)_{3}, \mathrm{~A}_{7} \mathrm{C}\left(\mathrm{XO}_{4}\right)_{6}, \mathrm{~A}_{3}^{\prime} \mathrm{A}_{5}\left(\mathrm{XO}_{4}\right)_{6}$ where $\mathrm{A}=$ divalent cation, $\mathrm{A}^{\prime}=$ monovalent cation, $\mathrm{B}=$ trivalent cation, $\mathrm{C}=$ tetravalent cation, and $\mathrm{X}=$ pentavalent cation [9-13]. Compounds with mixed tetrahedral site cations, namely $\mathrm{Pb}_{4}\left(\mathrm{PO}_{4}\right)_{2} \mathrm{CrO}_{4}$ and $\mathrm{Pb}_{4}\left(\mathrm{PO}_{4}\right)_{2} \mathrm{SO}_{4}$ have also been reported by Barbier $[14,15]$. However, there are very few single-crystal structures analyzed amongst this class of materials. The first single-crystal data of a eulytite phosphate $\mathrm{Ba}_{3} \mathrm{Bi}\left(\mathrm{PO}_{4}\right)_{3}$, was reported in 2000 by Arbib et al. [16]. Subsequently two other single-crystal data of eulytites

\footnotetext{
* Corresponding author. Tel.: +91 80 22932796; fax: +91 8023601310 .

E-mail address: ssctng@sscu.iisc.ernet.in (T.N. Guru Row).
}

are reported in the literature, which are $\mathrm{Na}_{3} \mathrm{Bi}_{5}\left(\mathrm{PO}_{4}\right)_{6}$ and $\mathrm{Pb}_{3} \mathrm{~V}\left(\mathrm{PO}_{4}\right)_{3}[17,18]$. The eulytites, especially BSO and BGO are known to have potential application as high-efficient scintillators in gamma ray spectroscopy and high-energy physics, lasers, etc. [19-24]. Luminescent materials have been fabricated with these eulytite classes of compounds and their photo luminescent spectra under VUV-UV excitation has been discussed in detail $[25-28,19]$. Since these materials belong to the non-centro symmetric space group, piezoelectric property can also be investigated for potential applications.

Though the structures of all eulytites appear to be similar, the local structural features associated with anionic and cationic distribution provides a variety adding complexity to the exhibited properties. The first classification of eulytites comprised of four categories, which is described by Arbib et al. [16]. The main reason for scantily available single-crystal data of eulytites is the inherent difficulty associated with growing the single crystals due to incongruent melting point, thermal instabilities, etc. During the synthesis of the title compound the authors have also faced this problem of incongruent melting. Moreover the determination of accurate occupancies of lead and bismuth is difficult due to the scattering factors of the two elements are nearly the same, since they differ only by one atomic number. So far there are no singlecrystal data available for vanadate eulytites. The unit cell of the compound has been reported [PDF no. 440646] to belong to the space group $I \overline{4} 3 d$ with $a=10.74 \AA, V=1240.39 \AA^{3}$ [29]. 


\section{Experimental}

\subsection{Materials}

$\mathrm{Bi}_{2} \mathrm{O}_{3}$ (Aldrich, 99.9\%) was dried at $350{ }^{\circ} \mathrm{C}$ for $6 \mathrm{~h}$ before use. $\mathrm{V}_{2} \mathrm{O}_{5}$ (BDH England, 99.9\%) and $\mathrm{PbO}$ (Alfa Aesar, 99.9\%) were used as received.

\subsection{Preparation and crystal growth}

The starting materials $\mathrm{PbO}, \mathrm{Bi}_{2} \mathrm{O}_{3}$ and $\mathrm{V}_{2} \mathrm{O}_{5}$ were taken in the stoichiometric ratio according to the formula $\mathrm{Pb}_{3} \mathrm{BiV}_{3} \mathrm{O}_{12}$. The mixture of the starting reactants was initially ground well with the help of agate mortar and pestle. The resultant mixture was put for heat treatment for 2 days at $650{ }^{\circ} \mathrm{C}$ in an open platinum crucible. Minor impurity in addition to the eulytite phase was present in the resultant product, which did not disappear even on further heating, as seen from the powder X-ray diffraction studies. Attempts to quench the sample at various temperature ranges also did not result in a pure phase. Upon further heating the powder at $800{ }^{\circ} \mathrm{C}$, it melted incongruently. In order to get the single crystals of the desired phase, the ratio of the starting materials $\mathrm{PbO}, \mathrm{Bi}_{2} \mathrm{O}_{3}$ and $\mathrm{V}_{2} \mathrm{O}_{5}$ was changed to $3: 1: 2$ as an alternate expecting the formation of $\mathrm{Pb}_{3} \mathrm{BiV}_{3} \mathrm{O}_{12}$ along with $\mathrm{BiVO}_{4}$ which might not melt incongruently at $800^{\circ} \mathrm{C}$. The mixture was put for heat treatment for 2 days at $650{ }^{\circ} \mathrm{C}$. The resulting mass was ground well and subsequently put for melting at $800{ }^{\circ} \mathrm{C}$ for $2 \mathrm{~h}$. Then the melt was slowly cooled to $650^{\circ} \mathrm{C}$ with a rate of $5{ }^{\circ} \mathrm{C} / \mathrm{h}$ and further cooled to room temperature. The powder diffraction pattern remained the same before and after melting the sample. The presence of two kinds of single crystals was evident under the polarizing microscope. One being the orange $\mathrm{Pb}_{3} \mathrm{BiV}_{3} \mathrm{O}_{12}$ and the other one is the yellow $\mathrm{BiVO}_{4}$ [PDF no. 14-0688] with space group $I 2 / a$ and cell parameters $a=5.195 \AA, b=11.70 \AA \mathrm{A} c=5.092 \AA$ and $\beta=90.38^{\circ}$. Small orange single crystals of the title compound suitable for $\mathrm{X}$ ray diffraction were carefully selected under the microscope.

\subsection{Powder X-ray diffraction}

Powder diffraction data were collected using a Philips X-pert diffractometer with $\mathrm{Cu} \mathrm{K} \alpha$ radiation over the angular range $6^{\circ} \leq 2 \theta \leq 80^{\circ}$, with a step width of $0.02^{\circ}$. Le Bail profile analysis in the JANA2000 [30] suite was used to refine the X-ray diffraction data. The background was estimated by Legendre polynomial, and the peak shapes were described by a pseudo-Voigt function varying five profile coefficients.

The powder pattern having the composition accounting for $\mathrm{Pb}_{3} \mathrm{BiV}_{3} \mathrm{O}_{12}$ (before melting) contained a small amount of impurity along with the cubic eulytite phase. This was identified to be a derivative of the high temperature $\gamma$-phase of $\mathrm{Pb}_{3} \mathrm{~V}_{2} \mathrm{O}_{8}$ [32] which belongs to the space group $R \overline{3} m$ with cell parameters $a=5.7766(3)$, $c=20.4666$ (5). Upon melting, the rhombohedral phase becomes the dominant phase with $\mathrm{BiVO}_{4}$ as the minor phase. The profile fit of the sample, before and after melting is shown in Figs. 1 and 2 confirming the above observations. The reason of getting the high temperature $\gamma$-phase of $\mathrm{Pb}_{3} \mathrm{~V}_{2} \mathrm{O}_{8}$ at room temperature could be the stabilization of the phase by incorporation of $\mathrm{Bi}$ at $\mathrm{Pb}$ site. However, the description of the exact composition of the impurity phase and the mechanism of melting to form new phases are not easily understood.

The second composition with the ratio 3:1:2 resulting in the anticipated stoichiometric $\mathrm{Pb}_{3} \mathrm{Bi}_{2} \mathrm{~V}_{4} \mathrm{O}_{16}$ retain its identity even after the melting. The polycrystalline sample after melting could be easily recognized to have two phases, the eulytite phase and the $\mathrm{BiVO}_{4}$ phase. Fig. 3 describes the profile fit of the sample with the two phases and there are no uncertainties in these assignments.

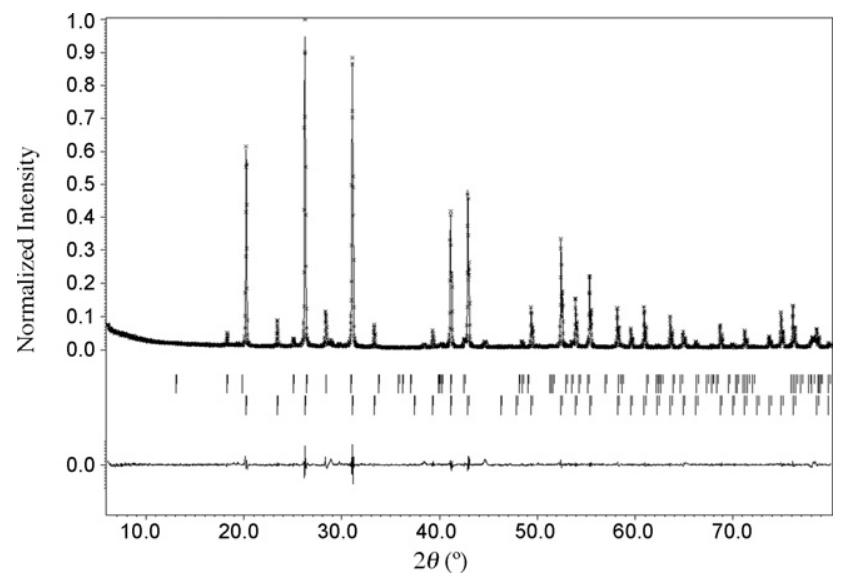

Fig. 1. Full pattern matching of the powder pattern of " $\mathrm{Pb}_{3} \mathrm{BiV}_{3} \mathrm{O}_{12}$ " before melting. The upper and lower rows of vertical marks correspond to the allowed reflections for $\gamma-\mathrm{Pb}_{3} \mathrm{~V}_{2} \mathrm{O}_{8}$-type and eulytite-type $\mathrm{Pb}_{3} \mathrm{Bi}\left(\mathrm{VO}_{4}\right)_{3}$ compounds, respectively.

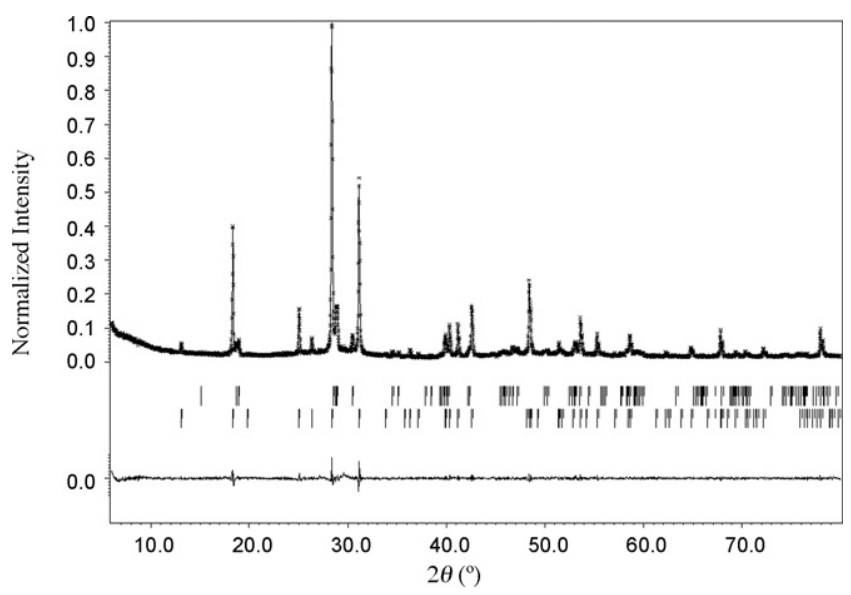

Fig. 2. Full pattern matching of the powder pattern of " $\mathrm{Pb}_{3} \mathrm{BiV}_{3} \mathrm{O}_{12}$ " after melting. The upper and lower rows of vertical marks correspond to the allowed reflections for $\mathrm{BiVO}_{4}$ and $\gamma-\mathrm{Pb}_{3} \mathrm{~V}_{2} \mathrm{O}_{8}$-type compound, respectively.

\subsection{Diffraction data collection}

An orange, block-shaped single crystal was selected on the basis of the size and sharpness of diffraction spots. Data collection was carried out on an Enraf-Nonius Kappa CCD diffractometer using a graphite monochromatized Mo $\mathrm{K} \alpha$

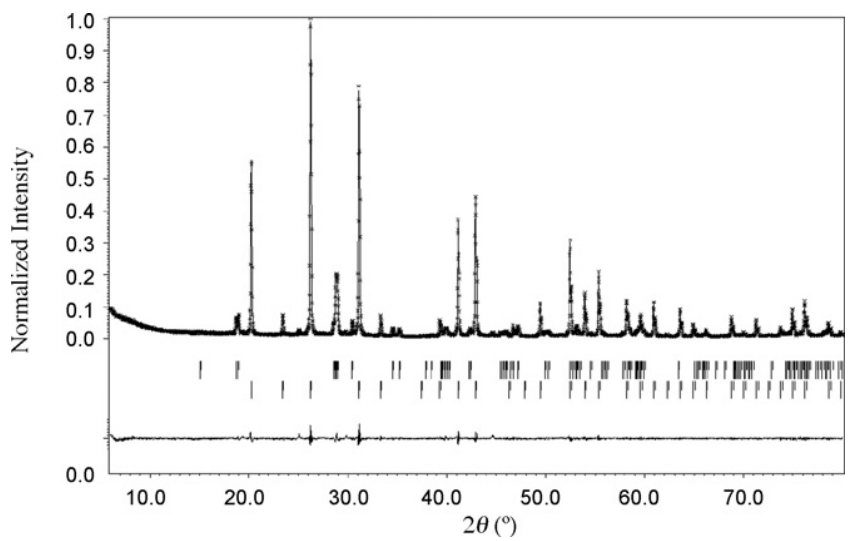

Fig. 3. Full pattern matching of the powder pattern of " $\mathrm{Pb}_{3} \mathrm{Bi}_{2} \mathrm{~V}_{4} \mathrm{O}_{16}$ " after melting The upper and lower rows of vertical marks correspond to the allowed reflections for $\mathrm{BiVO}_{4}$ and eulytite-type $\mathrm{Pb}_{3} \mathrm{Bi}\left(\mathrm{VO}_{4}\right)$ compound, respectively. 
Table 1

Crystallographic data collection and structure refinement of $\mathrm{Pb}_{3} \mathrm{Bi}\left(\mathrm{VO}_{4}\right)_{3}$.

\begin{tabular}{|c|c|}
\hline Empirical formula & $\mathrm{Pb}_{3} \mathrm{BiV}_{3} \mathrm{O}_{12}$ \\
\hline Formula weight & 1175.4 \\
\hline Crystal habit, colour & Block, orange \\
\hline Crystal size (mm) & $0.032 \times 0.021 \times 0.017$ \\
\hline Temperature (K) & 293(2) \\
\hline Radiation & Mo K $\alpha$ \\
\hline Wavelength $(\AA)$ & 0.71069 \\
\hline Crystal system & Cubic \\
\hline Space group & $I \overline{4} 3 d$ \\
\hline$a(\AA)$ & $10.7490(7)$ \\
\hline Volume $\left(\AA^{3}\right)$ & $1241.95(14)$ \\
\hline$Z$ & 4 \\
\hline Density $\left(\mathrm{g} \mathrm{cm}^{-3}\right)$ & 6.284 \\
\hline$F\left(\begin{array}{lll}0 & 0 & 0\end{array}\right)$ & 1976 \\
\hline Scan mode & $\omega$ scan $+\phi$ scan \\
\hline$\theta_{\max }\left({ }^{\circ}\right)$ & 31.93 \\
\hline$h_{\min , \max }, k_{\min , \max }, l_{\min , \max }$ & $(-16,15),(-16,16),(-16,16)$ \\
\hline No. of reflections measured & 11,817 \\
\hline No. of unique reflections & 359 \\
\hline Absorption correction & Gaussian \\
\hline$\mu\left(\mathrm{mm}^{-1}\right)$ & 56.843 \\
\hline No. of parameters & 15 \\
\hline Refinement & $F^{2}$ \\
\hline$R \_a l l, R \_o b s$ & $0.0254,0.0198$ \\
\hline$w R_{2 \_}$all, $w R_{2 \_} o b s$ & $0.0398,0.0384$ \\
\hline GoF & 1.30 \\
\hline $\operatorname{Max} / \min \Delta \rho$ e $\left(\AA^{3}\right)$ & $1.02,-0.90$ \\
\hline
\end{tabular}

wavelength ( $\left.\lambda_{\text {Mo }} K_{\alpha}=0.71069 \AA\right)$ radiation at $293(2) \mathrm{K}$. The diffraction intensities were corrected for Lorentz and polarization effects. Data processing and all of the refinements were performed with the JANA2000 program package [30]. The shape was determined with the video microscope of the Kappa CCD and a Gaussian type absorption correction was applied. Details about data collection and structure refinement are summarized in Table 1. The structure was solved using SHELXL-93 program [31] from 359 independent reflections, having $I \geq 3 \sigma(I)$. Atomic positions of $\mathrm{Bi} / \mathrm{Pb}$ and $\mathrm{V}$ were determined using direct method. Subsequent difference Fourier synthesis allowed locating the oxygen atom. The final refinement of the structure was achieved using a fixed site occupancy ratio $3: 1$ for $\mathrm{Pb}$ and $\mathrm{Bi}$ equal to the ideal values in accordance with the chemical formula $\mathrm{Pb}_{3} \mathrm{BiV}_{3} \mathrm{O}_{12}$. The atomic and thermal parameters of bismuth were fixed to be same as that of lead. The Flack parameter was refined to $0.02(3)$ and then fixed to 0 . The final residual factors are $R_{1}=0.0198$ and $w R_{2}=0.0384$. Because of the difference in atomic number of only one electron, X-ray analysis does not allow us to distinguish between the atoms $\mathrm{Pb}$ and $\mathrm{Bi}$. As evident, neutron diffraction studies will give better insights into the exact distribution and coordination of $\mathrm{Pb} / \mathrm{Bi}$, however it might be pointed that vanadium
Table 4

Selected bond lengths and bond angles of $\mathrm{Pb}_{3} \mathrm{Bi}\left(\mathrm{VO}_{4}\right)_{3}$.

\begin{tabular}{llll}
\hline Bond length Type & Distances $(\AA)$ & Bond angle type & Angles $\left(^{\circ}\right)$ \\
\hline $\mathrm{V}-\mathrm{O}$ & $1.709(5) \times 4$ & $\mathrm{O}-\mathrm{V}-\mathrm{O}$ & $112.2(2) \times 2$ \\
& & & $108.1(2) \times 4$ \\
$\mathrm{~Pb} / \mathrm{Bi}-\mathrm{O}$ & & $\mathrm{O}-\mathrm{Pb} / \mathrm{Bi}-\mathrm{O}$ & $71.80(17) \times 3$ \\
& $2.705(5) \times 3$ & & $82.27(17) \times 3$ \\
& $2.308(5) \times 3$ & & $82.31(19) \times 3$ \\
& & $115.26(16) \times 3$ \\
& & $151.36(17) \times 3$ \\
\end{tabular}

is neutron transparent. Atomic coordinates and isotropic displacement parameters are given in Table 2. Anisotropic displacement parameters (ADPs) and selected inter-atomic distances and angles are given in Tables 3 and 4 .

\section{Results and discussion}

The general feature of the reported eulytite structure is described in Fig. 4. This structure does not show any significant deviation from earlier reported eulytites. The structure consists of $\left[\mathrm{VO}_{4}\right]^{3-}$ tetrahedra and $\mathrm{Pb} / \mathrm{Bi}$ octahedra. While the octahedra share edges with each other and form a three-dimensional network, the $\left[\mathrm{VO}_{4}\right]^{3-}$ tetrahedra share all their vertices with the octahedra. Figs. 5 and 6 describe these features. As reported earlier [16,17], the $\left[\mathrm{VO}_{4}\right]^{3-}$ anionic tetrahedra shows pentagonal channels along $\left\langle\begin{array}{llll}0 & 0 & 1\rangle\end{array}\right\rangle$ direction (Fig. 7).

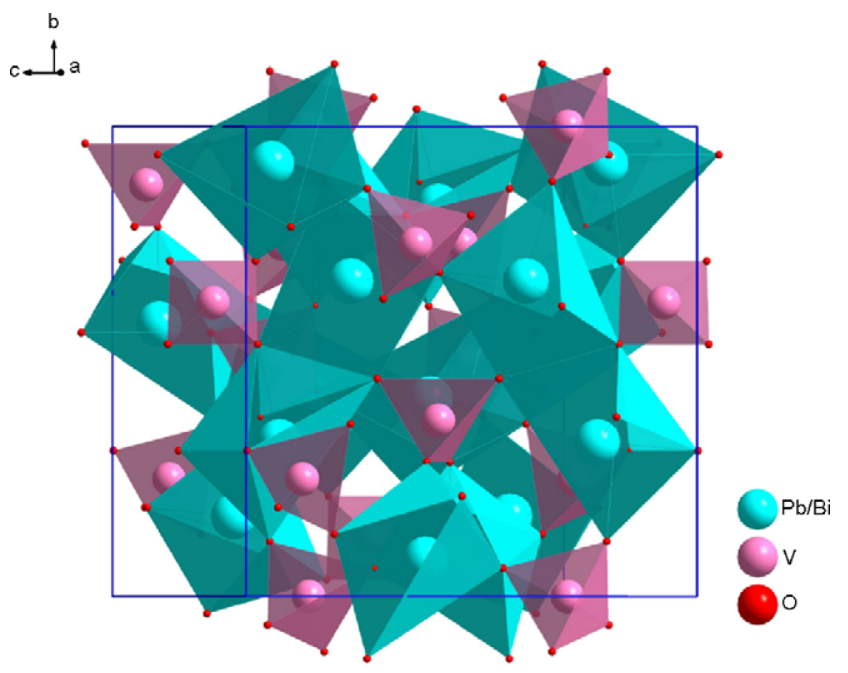

Fig. 4. Three-dimensional view of eulytite $\mathrm{Pb}_{3} \mathrm{Bi}\left(\mathrm{VO}_{4}\right)_{3}$.

Table 2

Atomic coordinates $(\AA)$ and isotropic displacement parameters $\left(\AA^{2}\right)$ for $\mathrm{Pb}_{3} \mathrm{Bi}\left(\mathrm{VO}_{4}\right)_{3}$.

\begin{tabular}{|c|c|c|c|c|c|}
\hline Atomic and Wycoff position & $x$ & $y$ & $z$ & $U_{\text {eq }}\left(\AA^{2}\right)$ & Occupancy \\
\hline $\mathrm{Pb} / \mathrm{Bi}(16 c)$ & $-0.07924(2)$ & $\times$ & $\times$ & $0.01496(6)$ & 1 \\
\hline $\mathrm{V}(12 b)$ & $-3 / 8$ & 0 & $-1 / 4$ & $0.0094(4)$ & 1 \\
\hline $\mathrm{O}(48 e)$ & $0.3105(5)$ & $0.9636(4)$ & $-0.1174(5)$ & $0.0220(16)$ & 1 \\
\hline
\end{tabular}

Table 3

Anisotropic displacement parameters $\left(\AA^{2}\right)$ of $\mathrm{Pb}_{3} \mathrm{Bi}\left(\mathrm{VO}_{4}\right)_{3}$.

\begin{tabular}{|c|c|c|c|c|c|c|}
\hline Atom & $U_{11}$ & $U_{22}$ & $U_{33}$ & $U_{12}$ & $U_{13}$ & $U_{23}$ \\
\hline $\mathrm{Pb} / \mathrm{Bi}$ & $0.01496(11)$ & $\mathrm{U}_{11}$ & $\mathrm{U}_{11}$ & $-0.00146(9)$ & $\mathrm{U}_{12}$ & $-\mathrm{U}_{12}$ \\
\hline V & $0.0105(6)$ & $0.0070(9)$ & $\mathrm{U}_{11}$ & 0 & 0 & 0 \\
\hline 0 & $0.032(3)$ & $0.017(3)$ & $0.017(2)$ & $-0.005(2)$ & $0.009(2)$ & $0.0040(18)$ \\
\hline
\end{tabular}




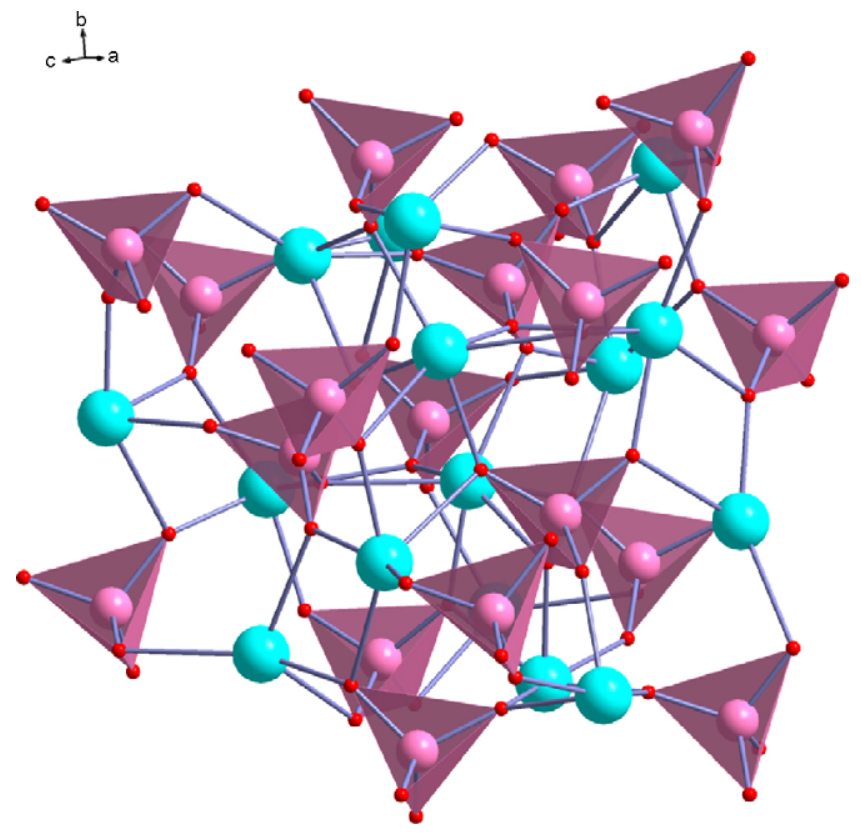

Fig. 5. View of the structure depicting isolated $\left[\mathrm{VO}_{4}\right]^{3-}$ tetrahedra.

The bond lengths and angles are consistent with previously reported distances. All the $\mathrm{V}-\mathrm{O}$ bonds are identical in $\left[\mathrm{VO}_{4}\right]^{3-}$ tetrahedra which is equal to $1.709(5) \AA$. However the $\mathrm{O}-\mathrm{V}-\mathrm{O}$ bond angles deviate significantly from the regular tetrahedral angle of $109.48^{\circ}$ indicating distortion in the tetrahedra. The $\mathrm{Pb} / \mathrm{Bi}$ sites have three short distances and three long distances. They are 2.308(5) $\AA$ and 2.705(5) $\AA$ for short and long distance, respectively. This difference between the two sets of distances is explained by the presence of the lone-pair on $\mathrm{Pb}^{2+}$ and $\mathrm{Bi}^{3+}$. A small difference of the oxygen surrounding around both cations may explain the relatively large value of the ADP component $U_{11}$ of the oxygen position (Table 3 ).

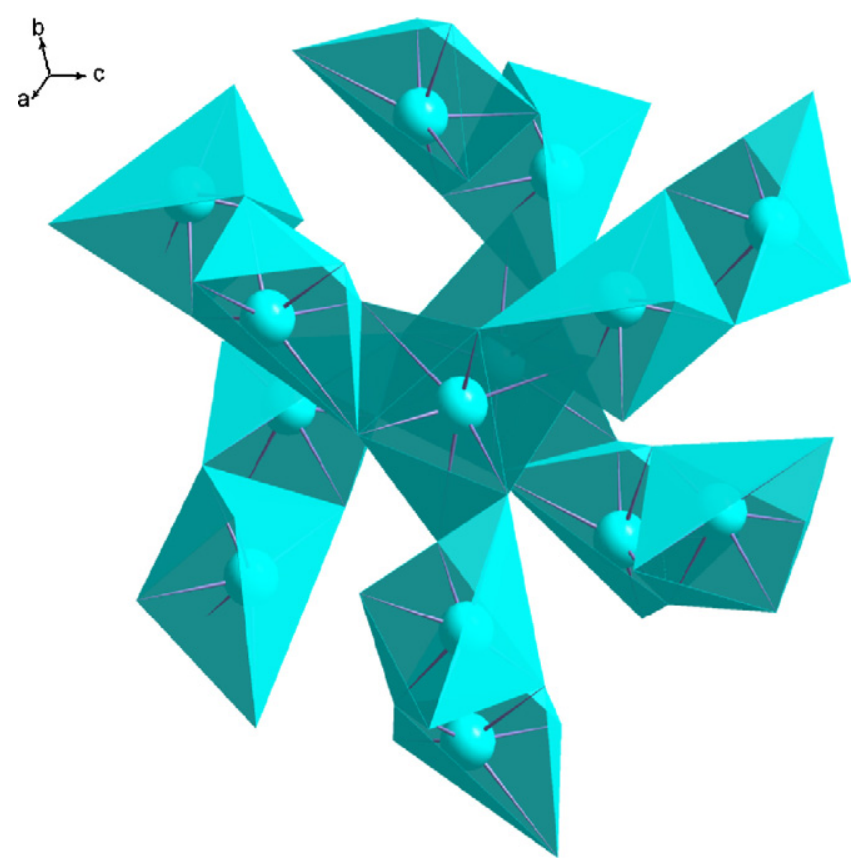

Fig. 6. View of the structure showing edge-shared $\mathrm{Pb} / \mathrm{Bi}$ octahedra.

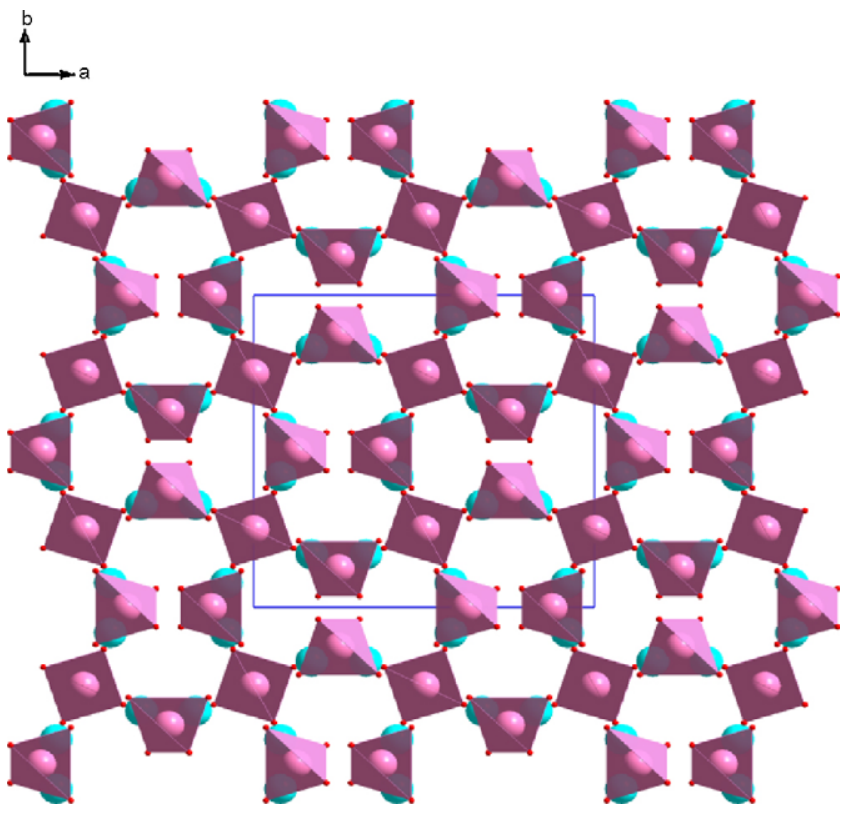

Fig. 7. Three-dimensional view of eulytite along $\left\langle\begin{array}{llll}0 & 0 & 1\end{array}\right\rangle$ showing pentagonal channels formed by $\left[\mathrm{VO}_{4}\right]^{3-}$ tetrahedra.

\section{Conclusions}

As the structure of a vanadate eulytite is not available in the literature we compare $\mathrm{Pb}_{3} \mathrm{BiV}_{3} \mathrm{O}_{12}$ with the eulytites already reported in the literature. The single-crystal structures available for eulytites till now, suggest diversity with respect to cationic and anionic sites. The structure is completely ordered in case of BGO and BSO with one oxygen site, whereas two oxygen sites of different occupancies have been suggested for $\mathrm{Pb}_{4}\left(\mathrm{PO}_{4}\right)_{2} \mathrm{SO}_{4}$, $\mathrm{Ca}_{3} \mathrm{Bi}\left(\mathrm{PO}_{4}\right)_{3}, \mathrm{Ba}_{3} \mathrm{La}\left(\mathrm{PO}_{4}\right)_{3}$, and $\mathrm{Ba}_{3} \mathrm{Bi}\left(\mathrm{PO}_{4}\right)_{3}$. On the other hand, three oxygen sites were identified for $\mathrm{Sr}_{3} \mathrm{La}\left(\mathrm{PO}_{4}\right)_{3}$ and $\mathrm{Pb}_{3} \mathrm{~V}\left(\mathrm{PO}_{4}\right)_{3}$. In case of $\mathrm{Na}_{3} \mathrm{Bi}_{5}\left(\mathrm{PO}_{4}\right)_{6}$ one oxygen site and two distinguished cationic positions were assigned for $\mathrm{Na}$ and $\mathrm{Bi}$. Also, in the case of $\mathrm{Pb}_{3} \mathrm{~V}\left(\mathrm{PO}_{4}\right)_{3}$ an unusual feature is the presence of $\mathrm{VO}_{6}$ octahedra which do not share edges or vertices. In the present study, one oxygen position is identified while one mixed cationic position for $\mathrm{Pb} / \mathrm{Bi}$ is identified. Combination of both neutron and X-ray diffraction studies would enable us to determine the exact occupancies of lead and bismuth. Determination of sizable number of single-crystal structures in eulytite class would probably enable one to categorize various subclasses in this system.

\section{Supporting information available}

CIF: the crystal data have been deposited at the Fachinformationszentrum Karlsruhe (FIZ) with the number CSD 419631.

\section{Acknowledgement}

PPS thanks LAFICS (IFLACS) for financial support.

\section{References}

[1] G. Menzer, Z. Kristallogr. 78 (1931) 136.

[2] D.J. Segal, R.P. Santoro, R.E. Newnham, Z. Kristallogr. 123 (1966) 73

[3] A. Durif, M.T. Averbuch-Pouchot, C. R. Acad. Sci. Paris 295B (1982) 555.

[4] P. Fischer, F. Waldner, Solid State Commun. 44 (1982) 657.

[5] S.F. Radaev, L.A. Muradyan, Y.F. Kargin, V.A. Sarlin, V.N. Kanepit, V.I. Simonov, Sov. Phys. Crystallogr. 35 (2) (1990) 204.

[6] T.I. Milenov, P.M. Rafailov, R. Petrova, Yu.F. Kargin, M.M. Gospodinov, Mater. Sci. Eng. B 138 (2007) 35. 
[7] J. Liebertz, J. Cryst. Growth 5 (1969) 150.

8] H. von Philipsborn, J. Cryst. Growth 11 (1971) 348.

[9] K. Fukuda, T. Iwata, T. Niwa, J. Solid State Chem. 179 (11) (2006) 3420.

[10] H. Liang, Y. Tao, Q. Su, Mater. Sci. Eng. B: Solid-State Mater. Adv. Technol. B119 (2) (2005) 152.

[11] K. Fukuda, H. Matsubara, K. Fukutani, H. Yoshida, Powder Diffr. 19 (4) (2004) 385

[12] J. Barbier, Can. J. Solid State Chem. 101 (2) (1992) 249.

[13] G.J. McCarthy, D.E. Pfoertsch, J. Solid State Chem. 38 (1) (1981) 128.

[14] J. Barbier, J. Solid State Chem. 101 (1992) 249

[15] J. Barbier, Eur. J. Solid State Inorg. Chem. 31 (1994) 163.

[16] E. Arbib, B. Elouadi, J.P. Chaminade, J. Darriet, Mater. Res. Bull. 35 (2000) 761.

[17] E. Arbib, J.P. Chaminade, J. Darriet, B. Elouadi, Solid State Sci. 2 (2000) 243.

[18] R.V. Shpanchenkoa, R.V. Panina, J. Hadermannb, C. Bougerolc, E. TakayamaMuromachid, E.V. Antipova, J. Solid State Chem. 178 (2005) 3715.

[19] H.F. Folkerts, J. Zuidema, G. Blasse, Chem. Phys. Lett. 249 (1-2) (1996) 59.

[20] G. Blasse, Chem. Mater. 6 (9) (1994) 1465.

[21] M.V. Lalic, S.O. Souza, Opt. Mater. 30 (2008) 1189.
[22] M. Ishii, K. Harada, Y. Hirose, N. Senguttuvan, M. Kobayashi, I. Yamaga, H. Ueno, K. Miwa, F. Shiji, F. Yiting, M. Nikl, X.Q. Feng, Opt. Mater. 19 (1) (2002) 201.

[23] T. Znamierowska, W. Szuszkiewicz, J. Hanuza, L. Macalik, D. Hreniak, W. Stręk, J. Alloys Compd. 341 (1-2) (2002) 371.

[24] X.-Q. Feng, G.-Q. Hu, Z.-W. Yin, Y.-P. Huang, S. Kapphan, C. Fisher, F.-Z. Zhou, Y Yang, D.-Y. Fan, Mater. Sci. Eng. B 23 (2) (1994) 83

[25] H. Liang, Y. Tao, J. Xu, H. He, H. Wu, W. Chen, S. Wang, Q. Su, J. Solid State Chem 177 (3) (2004) 901.

[26] M.F. Hoogendorp, W.J. Schipper, G. Blasse, J. Alloys Compd. 205 (1-2) (1994) 249

[27] X. Xiao, S. Xu, B. Yan, J. Alloys Compd. 429 (1-2) (2007) 255.

[28] M.J.J. Lammers, H.C.G. Verhaar, G. Blasse, Mater. Chem. Phys. 16 (1) (1987) 63.

[29] R. Ludwig, W. Eysel, Mineral.-Petrograph Institut, Universitaet Heidelberg, Germany, ICDD Grant-in-Aid (1993).

[30] M. Dušek, V. Petřiček, M. Wunschel, R.E. Dinnebier, S. van Smaalen, J. Appl. Crystallogr. 34 (2001) 398

[31] SHELXS-97 - A program for automatic solution of crystal structure. G.M. Sheldrick, University of Goettinngen, Germany, 1997, Release 97-2.

[32] J.M. Kiat, P. Garnier, M. Pinot, J. Solid State Chem. 91 (1991) 339. 